\title{
Ne plus ultra
}

Citation for published version (APA):

de Leeuw, P. W. (1992). Ne plus ultra. Rijksuniversiteit Limburg. https://doi.org/10.26481/spe.19920416pl

Document status and date:

Published: 16/04/1992

DOI:

10.26481/spe.19920416pl

Document Version:

Publisher's PDF, also known as Version of record

\section{Please check the document version of this publication:}

- A submitted manuscript is the version of the article upon submission and before peer-review. There can be important differences between the submitted version and the official published version of record.

People interested in the research are advised to contact the author for the final version of the publication, or visit the DOI to the publisher's website.

- The final author version and the galley proof are versions of the publication after peer review.

- The final published version features the final layout of the paper including the volume, issue and page numbers.

Link to publication

\footnotetext{
General rights rights.

- You may freely distribute the URL identifying the publication in the public portal. please follow below link for the End User Agreement:

www.umlib.nl/taverne-license

Take down policy

If you believe that this document breaches copyright please contact us at:

repository@maastrichtuniversity.nl

providing details and we will investigate your claim.
}

Copyright and moral rights for the publications made accessible in the public portal are retained by the authors and/or other copyright owners and it is a condition of accessing publications that users recognise and abide by the legal requirements associated with these

- Users may download and print one copy of any publication from the public portal for the purpose of private study or research.

- You may not further distribute the material or use it for any profit-making activity or commercial gain

If the publication is distributed under the terms of Article $25 \mathrm{fa}$ of the Dutch Copyright Act, indicated by the "Taverne" license above, 


\section{NE PLUS ULTRA}

Rede

uitgesproken bij de aanvaarding van het ambt van gewoon hoogleraar in de Interne Geneeskunde, in het bijzonder de Hypertensie en de Nefrologie, aan de Rijksuniversiteit Limburg te Maastricht op 16 april 1992

door

Dr. P.W. de Leeuw 
Ter nagedachtenis aan mijn vader. 
Mijnheer de Rector Magnificus,

Leden van het College van Bestuur der Rijksuniversiteit Limburg,

Dames en Heren Hoogleraren en leden van de Wetenschappelijke Staf,

Dames en Heren Studenten,

en voorts Gij allen, die deze bijeenkomst met uw aanwezigheid opluistert,

\section{Zeer gewaardeerde toehoorders,}

$U$ bent hier naar toe gekomen (sommigen zelfs van verre) voor het aanhoren van een inaugurele rede, en dan nog wel één met een zo bizarre titel. Alvorens nader in te gaan op de betekenis van deze titel wil ik even met u stilstaan bij de vraag wat een inaugurele rede eigenlijk is, of wellicht zou moeten zijn. Wanneer men de teksten van een aantal redes, zoals deze de laatste jaren op diverse plaatsen in Nederland zijn gehouden, nog eens doorleest valt op dat hierin doorgaans een beeld wordt geschetst van de verworvenheden binnen een bepaald vakgebied, al dan niet gelardeerd met enkele wapenfeiten van de verse hoogleraar op het betreffende terrein. In de 'regeling der inaugurale redes' van de Rijksuniversiteit Limburg leest men dat het doel van een inaugurele rede is dat de nieuwe hoogleraar een toelichting geeft op zijn/haar vakgebied en zich op deze wijze aan de universitaire gemeenschap voorstelt. Daarbij dient de inhoud van de rede zo eenvoudig mogelijk te zijn en ook voor leken begrijpelijk. Het is echter de vraag of een op deze wijze geformuleerde doelstelling wel altijd haalbaar is. Immers, als gevolg van toenemende differentiatie binnen de geneeskundle in het algemeen en binnen het domein van de interne ziekten in het bijzonder, loopt men als representant van een bepaald deelgebied al snel het risico als leek te worden beschouwd wanneer het om een ander deelgebied gaat, zelfs al is de grens tussen dergelijke gebieden soms vaag. Elke rede, zo ook deze, dreigt dan ook te kort te schieten waar het gaat om de balans tussen de puur wetenschappelijke en de meer populaire schets van het betreffende vakgebied.

Maar laten wij eens bezien waarop de hedendaagse traditie van het inaugureren berust. Hiervoor moeten wij terug naar de Romeinse tijd. Het latijnse woord 'inaugurare' heeft een tweeledige betekenis, namelijk enerzijds 'raadplegen van de auguren' en anderzijds 'het met godsdienstige riten installeren of inwijden'. Auguren waren leden van het Romeinse priestercollege wier taak het was om door waarneming en uitlegging van bepaalde (voor)tekenen vast te stellen of de goden een (meestal van 
staatswege) voorgenomen daad goed of afkeurden. De augur die het "auspicium" hield, nam daartoe de vlucht of het geschreeuw van bepaalde vogels waar. Staande met het gelaat nar het zuiden gericht, had hij het gelukbrengende oosten aan de linkerhand; verschijnselen aan die zijde werden dan ook als positief ervaren. Interessant is overigens dat bij de Grieken, die er een soortgelijk ritueel op nahielden, de augur zich naar het noorden richtte zodat bij hen tekenen ter linkerzijde juist als ongunstig werden uitgelegd. Hiermee zij meteen geillustreerd dat dezelfde warnemingen tot diametraal tegenover elkaar staande interpretaties kunnen leiden, afhankelijk van de positie die de waarnemer ten opzichte van het waargenomene inneemt. Overigens lette men ook op andere tekenen dan alleen de vlucht of het gekrijs van wogels; donder, bliksem en het al dan niet gulzig vreten van de heilige kippen golden als minstens zo belangrijke fenomenen. Wanneer de voortekenen gunstig waren, kon een geplande vergadering doorgang vinden, een militaire actie worden goedgekeurd of, zoals nu, een ambtsaanvaarding bevestigd. Voortbordurend op deze oude gewoonte is ons inaugureren dus niets anders dan het onder het waarnemen der voortekenen installeren van de nieuwe hoogleraar. Mutatis mutandis kan men daarbij de universitaire gemeenschap opvatten als de magistraat die het raadplegen van de auspicia entameert, waarbij de nieuwe hoogleraar in de rol van augur gedrongen wordt. Dat het godsdienstig element daarbij niet geheel wordt overgeslagen, moge blijken uit onze ietwat pauselijk aandoende kledij, het religieuze decor en het feit dat aan het eind van deze oratie de veertigdaagse periode van vasten voorbij is.

Hoewel het voorspellen van de toekomst in onbruik is geraakt en bepaaldelijk niet als een academische taak wordt ervaren, meen ik toch dat een inaugurele rede best een element van toekomstverwachting mag bevatten. Per slot van rekening gedraagt de moderne medicus zich hetzij als klinicus, hetzij als wetenschapper in zekere zin ook als augur. Op basis van waarneming en uitlegging immers doet ook hij voorspellingen ten aanzien van de uitkomsten van toekomstig onderzoek of van een bepaalde behandeling. De wijze waarop hij zijn metingen interpreteert is daarbij afhankelijk van de richting waarin hij theoretisch gevormd is of waarnaar hij, om bij de klassieken te blijven, zijn blik richt.

Met dit in gedachten heb ik als titel voor deze rede en als centraal thema in mijn betoog de uitdrukking "Ne Plus Ultra" gekozen. Voor degenen onder u bij wie deze woorden geen associaties oproepen, zal ik in het kort uitleggen wat de betekenis hiervan is. Het motto 'Ne Plus Ultra' wordt traditioneel in 
verband gebracht met de zuilen van Hercules bij de Straat van Gibraltar. Deze zuilen met de inscriptie 'Ne Plus Ultra' vormden onderdeel van het wapen van het Spaanse koningshuis in de vijftiende eeuw. De betekenis van de spreuk luidt: aan gene zijde is er niets meer. Aldus symboliseerde het heraldische embleem een wereldbeeld waarin Spanje de frontlinie vormde waar voorbij geen land of leven was, de grens van de wereld. Zoals u allen echter weet, kwam aan dit beeld een einde toen, dit jaar precies 500 jaar geleden, de heer Columbus een nieuwe wereld ontdekte. Het opportunistische Spaanse hof restte daarop niets anders dan het verwijderen van het woord 'Ne' uit het embleem. Nu stond er dus: 'Plus Ultra', aan gene zijde is meer, waarop het wapen symbool werd van de toegang tot de nieuwe wereld met uiteraard Spanje als toegangspoort. Datgene wat aanvankelijk voor een absolute grens was gehouden, was nu verdwenen.

Uiteraard is het veel veiliger om niet over toekomstige ontwikkelingen en nieuwe grenzen als een mogelijk 'Plus Ultra' te spreken, maar over de reeds in het vakgebied bereikte en op dit moment als absoluut ("Ne Plus Ultra') aanvaarde resultaten. Desalniettemin wil ik u, op het gevaar af daarbij te verzanden in het soort waarzeggerij van Nostradamus (zoals u weet, ook een medicus), naast een schets van de status praesens van mijn vakgebied, de interne geneeskunde, toch enkele gedachten voorleggen met betrekking tot mogelijke veranderingen op dit terrein. Daarbij zal waarschijnlijk blijken dat de wens weer eens de vader is van deze gedachten, maar voor deze ene gelegenheid permitteer ik mij deze vrijheid.

Omdat mijn benoeming de interne geneeskunde in het bijzonder de hypertensie en de nefrologie betreft, zal ik in mijn betoog vooral de aandacht daarop richten.

\section{Interne geneeskunde als klinisch specialisme.}

De interne geneeskunde heeft in deze eeuw belangrijke wijzigingen ondergaan. Waar de internist aanvankelijk iemand was die een breed terrein van de geneeskunde kon overzien, ontnam de voortschrijdende deelspecialisatie hem de gelegenheid tot het handhaven van een integrale praktijkvoering. Binnen het vakgebied kent men thans een groot aantal deelgebieden zoals endocrinologie, gastroenterologie, nefrologie, hematologie, allergologie etcetera. Sommigen neigen ertoe om datgene wat niet onder een van deze deelgebieden valt, te rekenen tot de zogenaamde algemene interne geneeskunde. In enkele universiteitsklinieken, inclusief die van Maastricht, is dan ook een afdeling cq werkgroep 'algemene interne' 
ontstaan. Hoewel dit wellicht om organisatorische redenen nuttig kan zijn, is een dergelijke benaming vanuit principieel oogpunt onjuist en zelfs ongewenst. Op deze wijze formaliseert men immers een verschil in denkwijze en praktijkvoering tussen generalist en deelspecialist en bemoeilijkt men de weg terug naar reíntegratie. Ik zal dan ook, wanneer ik het heb over de interne geneeskunde, de term 'allgemene" vermijden.

Het deelgebied waarop mijn benoeming vooral betrekking heeft, is de nefrologie oftewel de leer der nieren. Vroeger werd hier alleen onder verstaan kennis van de normale en de zieke nier. Later is het accent in dit deelgebied steeds meer komen te liggen op dialyse en transplantatie. Binnen de nefrologie wordt men overigens geregeld geconfronteerd met problemen van algemene aard. Ik noem u de anemie bij nierinsufficientie, de circulatoire veranderingen tijdens behandeling met erythropoietine, de gestoorde vetstofwisseling en stollingsstoornissen bij patiënten met nefrotisch syndroom etcetera. Gezien de cruciale rol die de nier speelt bij de water- en zouthuishouding en bij de hormonale regulatie van de bloeddruk, is hypertensie (verhoogde bloeddruk) ook een belangrijk deel gaan uitmaken van de nefrologie.

Hypertensie is echter bij uitstek een voorbeeld van een aandoening die tot de interne geneeskunde gerekend moet worden en die zich niet aan het 'Ne Plus Ultra' van één aandachtsgebied houdt, zoals ik u hoop duidelijk te maken.

Bloeddrukverhoging kan als een op zichzelf staande afwijking voorkomen (de primaire of essentiële hypertensie), maar ook het gevolg zijn van bijvoorbeeld een vernauwing van de bloedvaten van de nier, van afwijkingen in het nierweefsel of van een toegenomen produktie van stoffen met een bloeddrukverhogend effect zoals bepaalde hormonen uit de bijnier. Zelfs de schildklier en de bijschildklier kunnen invloed uitoefenen op de regulatie van de bloeddruk. Het is dan ook duidelijk dat de internist die zich met hypertensiepatienten bezighoudt in ieder geval thuis moet zijn op het gebied van nieren en klieren.

Zoals bij de meesten wel bekend, gaat verhoogde bloeddruk gepaard met een toegenomen kans op beroerte of hartinfarct. Dit zijn zogenaamde eindpunten van een jarenlange ontwikkeling, gedurende welke een aantal bijkomende afwijkingen de kop kunnen opsteken zoals stoornissen in de vetstofwisseling en diabetes mellitus met insuline-resistentie. Deze zaken vereisen eveneens een op internistische leest geschoeide aanpak. Ook als men bijvoorbeeld als gevolg van andere ziekten niet aan de eindpunten 
toekomt, wordt door de drukverhoging toch belangrijke schade aangericht en niet alleen aan hart en hersenen, maar ook aan bloedvaten en aan de nier. Deze laatste vormen van orgaanschade komen gewoonlijk niet zo makkelijk aan het licht omdat de opsporingstechnieken die ons hiervoor ten dienste staan nog te ongevoelig zijn.

Wanneer wij een patiënt met hypertensie tenslotte willen behandelen, krijgen wij te maken met de ongewenste effecten van medicamenten, hetgeen ook weer betrekking kan hebben op stoornissen in de functie van diverse organen. In de praktijk richten wij ons daarbij vooral op het voorkomen van complicaties in hart en nieren. Ik hoop u hiermee duidelijk te maken dat de internist die de zorg heeft voor hypertensiepatienten 'in hart en nieren' internist moet zijn en dus zeker generalist dient te zijn.

Er zijn natuurlijk meer voorbeelden te geven van interne ziekten die zich over meerdere aandachtsgebieden uitstrekken zoals levercirrhose, diabetes mellitus en het chronisch obstructief longlijden. Hoewell voor al deze ziektebeelden geldt dat die het best door een echte internist aangepakt kunnen worden, blijkt vooral in de academische ziekenhuizen, maar in toenemende mate ook daarbuiten, dat meerdere internisten met ieder hun eigen aandachtsgebied zich met dit soort patiënten gaan bezighouden. Als men het ongeluk heeft op een intensive care afdeling te belanden, dan gebeurt het niet zelden dat men zelfs voor ieder orgaan dat niet naar behoren werkt, een andere specialist aan het bed krijgt. Natuurlijk trekt niemand de expertise van de afzonderlijke orgaanspecialisten in twijfel, maar hun respectievelijke adviezen zijn nog wel eens met elkaar in tegenspraak. De internist is dan nog de enige die enigszins het overzicht kan houden en de diverse afspraken in goede banen kan leiden, maar helaas wordt juist hij vaak beschouwd als de wat zielige figuur die het allemaal goed meent, maar te weinig specifieke kennis heeft.

Nu kunnen wij natuurlijk de huidige situatie waarin de interne geneeskunde als het ware uiteensplijt in deelspecialismen, die bij wijze van spreken nog slechts door enkele adhesie-moleculen verbonden worden, als een absoluut gegeven, een 'Ne Plus Ultra', aanvaarden en deze laten stabiliseren, maar het lijkt mij nuttiger om te zoeken naar oplossingen die de band tussen internist en deelspecialist en tussen deelspecialisten onderling weer aantrekken. Ik kom daar straks op terug, want wij moeten nu eerst eens bezien welke krachtlijnen het klinisch wetenschappelijk onderzoek in de interne geneeskunde, en meer in het bijzonder op het terrein van de hypertensie, beheersen. 


\section{Het klinisch wetenschappelijk onderzoek.}

Sprekend over onderzoek ontkom ik er in dit jaar 1992 natuurlijk niet aan om even stil te staan bij ến van de verstrekkendste gebeurtenissen in de wereldgeschiedenis, namelijk de ontdekking van Amerika door Christoffel Columbus, dit jaar precies 500 jaar geleden. Nadat Columbus van Genua naar Lissabon was verhuisd, werd hij naar aanleiding van enkele hier verder niet ter zake doende anekdotes gegrepen door de gedachte dat er in het westen merkwaardige landen te ontdekken moesten zijn. Hij vond voor deze hypothese steun in het werk van de uit Florence afkomstige cartograaf én medicus Toscanelli. Deze veronderstelde namelijk dat; als de theoretische studies van Ptolemaeus juist waren, het mogelijk moest zijn om Azië via het westen te bereiken. Bij deze gewaagde hypothese ging Toscanelli ervan uit dat de aarde rond moest zijn en dat de grootte van de aarde tot dan toe onderschat was. Vanaf ongeveer 1480 werkte Columbus aan plannen voor een expeditie naar de West en hij diende een verzoek in bij koning Johan de Tweede van Portugal voor financiële ondersteuning. Het werd hem geweigerd. Daarop vertrok Columbus naar Spanje waar hij na enige tijd zijn plannen kon voorleggen aan het koningshuis aldaar. Vervolgens werd een commissie gevormd die het voorstel moest bestuderen. Na vier jaar kwam deze commissie met haar oordeel dat een volledige afwijzing inhield. Met hulp van anderen slaagde Columbus er echter uiteindelijk toch in om de financiering rond te krijgen, waarvoor de overeenkomst getekend werd op 17 april 1492 , morgen dus 500 jaar geleden en ook voor hem een goede vrijdag. De verdere afloop is u bekend; Columbus ontdekte nieuw land in het westen dat hij op basis van de toen heersende opvattingen voor Azië hield. Pas tien jaar later stelde Amerigo Vespucci vast dat het om een geheel nieuw continent ging.

Ik grijp deze geschiedenis aan als parabel om te illustreren hoe het de moderne Columbus, de klinisch werkzame wetenschappelijk onderzoeker, kan vergaan bij zijn ontdekkingsreis naar de oorsprong en het natuurlijk beloop van ziekten. Wanneer wij de geschiedenis van Columbus in hedendaagse termen proberen te vatten, dan zouden wij kunnen zeggen dlat de onderzoeker op basis van anekdotische waarnemingen (lees: klinische impressies) en literatuurstudie een idee ontwikkelt dat hij vervolgens experimenteel probeert te bevestigen. Omdat voor het onderzoek geld nodig is, dient hij een subsidieaanvraag in bij een instantie die voor verdeling van de beschikbare gelden verantwoordelijk is. Vervolgens buigt een wetenschappelijke commissie zich over het voorstel, waarna zeker voor 
klinisch onderzoek niet zelden afwijzing volgt. Na enkele manipulaties en met hulp van anderen (niet zelden een farmaceutische industrie) lukt het dan vaak toch wel om het project gefinancierd te krijgen, waarna de expeditie kan beginnen, soms met verrassende resultaten.

In het geval van Columbus was er sprake van een goed uitgedachte studie, maar het project werd aanvankelijk niet gehonoreerd omdat het te risicodragend was, de hypothese die eraan ten grondslag lag werd te gewaagd bevonden. Niettemin heeft dit onderzoek letterlijk een ontdekking van wereldformaat opgeleverd. Het leidde tot een situatie waarin het ' $\mathrm{Ne}$ Plus Ultra' vervangen kon worden door 'Plus Ultra'.

Ook in de moderne wetenschap kennen wij tal van voorbeelden betreffende belangrijke ontdekkingen waarvoor de onderzoeker vooraf te weinig steun kreeg. Als leden van wetenschappelijke adviesraden of van redacties van wetenschappelijke tijdschriften zijn wij, internist of deelspecialist, namelijk al snel geneigd om ons op te stellen als een soort augur die op grond van voor de buitenwereld meestal slecht omschreven criteria uitspraken doet over het al dan niet acceptabel zijn van andermans onderzoek. Er bestaat daarbij een sterke neiging om onderzoek met gewaagde hypothesen en onzekere uitkomsten geen hoge prioriteit te geven of zelfs negatief te beoordelen. Men kan met enige overdrijving zelfs stellen dat de uitkomst van een onderzoek al bijna vast moet staan wil er subsidie voor verleend worden. Nu zal dat in een aantal gevallen zeker verdedigbaar zijn, maar toch werkt dit systeem verlammend op de voortgang van het wetenschappelijk onderzoek. Het leidt er toe dat subsidieaanvragers goed in de markt liggende protocollen zullen opstellen met weinig kans op mislukking. De ontdekkingen die vervolgens gedaan worden, worden in het gemeen geïnterpreteerd in het licht van bekende mechanismen en leiden dan ook meestal niet direct tot fundamentele doorbraken. Men is bovendien zo aan het protocol gebonden dat elke vorm van creatieve deviatie ogenblikkelijk in de kiem gesmoord dreigt te worden. Ik verwijs in dit kader graag naar de woorden van J.I.S. Robertson: "Columbus could not discover America because it was not in the protocol'.

De wijze waarop het wetenschappelijk onderzoek zich thans ontwikkelt is vooral compatibel met de formuleringen van de wetenschapsfilosoof Lakatos. Deze stelt namelijk dat de vooruitgang in kennis wordt bepaald door ketens van theorieën die door zogenaamde onderzoeksprogramma's worden voortgebracht. Deze programma's worden beheerst door, wat hij noemt, negatieve en positieve heuristiek, dat wil zeggen regels die aangeven 
welke wegen in het onderzoek niet of juist wel ingeslagen moeten worden. De regels van de negatieve heuristiek verbieden als het ware om de op een gegeven moment als absoluut aanvaarde uitgangspunten aan te vallen. Wanneer bepaalde bevindingen in strijd zijn met deze uitgangspunten, dan moet in de eerste plaats aan deze bevindingen getwijfeld worden en niet aan de uitgangspunten. Indien niet aan de uitkomsten van onderzoek getwijfeld kan worden, moeten de absolute uitgangspunten beschermd worden, het ' $\mathrm{Ne}$ Plus Ultra' gestabiliseerd, door nieuwe veronderstellingen en hulphypothesen (positieve heuristiek). Columbus kón geen nieuw land ontdekken omdat hij niet kon twijfelen aan het centrale uitgangspunt dat hij in Azië zou uitkomen. Alle ontdekkingen die volgden alsmede enkele niet goed te verklaren verschijnselen zoals de merkwaardige huidskleur van de inboorlingen die men tegenkwam, werden uitgelegd op een manier die bij dat uitgangspunt bleven aansluiten. Pas toen Vespucci zoveel anomalieën had gevonden dat het centrale uitgangspunt niet langer te handhaven was, kon op rationele gronden een nieuw uitgangspunt ontwikkeld worden, namelijk dat van het bestaan van een tot duswer onbekend land.

Het zou te ver voeren hier op alle aspecten van Lakatos' methodologie in te gaan, maar uit zijn werk wordt duidelijk dat zolang een programma feiten voortbrengt die tevoren niet bekend waren, het rationeel geacht moet worden om daarin verder te werken. Oordelen over de rationele inhoud van onderzoekprogramma's zijn evenwel feilbaar en mogen niet leiden tot adviezen omtrent het al dan niet doorwerken in een bepaald programma.

Evenals Popper overigens hecht Lakatos grote waarde aan het falsificatie-criterium. Dat wil zeggen dat vooruitgang in kennis vooral bepaald wordt door de mate waarin hypothesen ontkracht, gefalsifieerd kunnen worden. Niet het vinden van steun vóór bepaalde theorieẻn, maar juist het vinden van bewijzen die tegen die theorieën pleiten, levert een grotere bijdrage aan de ontwikkeling van kennis. Het doen van onderzoek met de vooropgezette bedoeling een theorie te falsifieren staat echter niet in hoog aanzien.

Zoals ik eerder stelde, is het huidige subsidiebeleid vooral gericht op steun aan weinig risicodragend onderzoek. Hiermee wordt dus in Lakatos" redeneertrant vooral de positieve heuristiek gesteund. Aangezien dergelijk onderzoek gezien moet worden als bestendiging van centrale uitgangspunten, zal het weliswaar nieuwe feiten, maar meestal geen falsificaties van theorieën opleveren. Zeer zeker zal onze kennis omtrent de onderzochte systemen toenemen, maar het is duidelijk dat op deze manier het creatieve 
element in de beoefening van de wetenschap zwaar op de proef wordt gesteld en zelfs met de ondergang bedreigd. Het zogenaamde risicodragende. onderzoek daarentegen toetst in het algemeen echter veel interessantere hypothesen en kan in sommige gevallen een onderzoekprogramma volledig doen veranderen. Wij moeten dus wel erg voorzichtig zijn met het negatief beoordelen van sommige projecten en wij mogen een aantal gefrustreerde onderzoekers wel dankbaar zijn dat zij ondanks gebrek aan steun toch volhard hebben in hun idee.

In het hypertensieonderzoek vinden wij het zojuist besprokene terug. Een wereldwijd probleem in de huidige klinische onderzoekprogramma's op het gebied van hypertensie is dat fundamentele vraagstellingen vaak blijven liggen en dat veel tijd en geld besteed wordt aan toevallige passanten in de pathofysiologie. Bij diverse gelegenheden heeft Birkenhäger al gewezen op de modieuze tendensen in het hypertensieonderzoek. Hij illustreerde dat aan de hand van bepaalde wandachtsgebieden in het onderzoek die op een zeker moment toegankelijk zijn geworden door de ontdekking van weer een nieuw hormoon of een andere onderzoektechniek. Dit leidt dan in de regel tot een explosie van gegevens die voortspruiten uit het werk van hitgevoelige onderzoekers. Het hemodynamisch onderzoek bij patiënten met een licht verhoogde bloeddruk is daarvan een sprekend voorbeeld. Ik zou daar aan toe kunnen voegen het onderzoek op het vlak van de zogenaamde zoutgevoeligheid. Hieronder wordt verstaan de mate waarin iemands bloeddruk oploopt wanneer hij meer zout gaat gebruiken. Overal ter wereld worden experimenten verricht met betrekking tot het fenomeen zoutgevoeligheid. Er wordt daarbij echter steeds uitgegaan van een arbitraire definitie van dit begrip, die van onderzoeker tot onderzoeker verschilt. Het onderzoek heeft dus wel een positief heuristisch karakter, maar het punt waar het werkelijk om draait (bestaat zoutgevoeligheid eigenlijk wel en zo ja, wat is dat dan) wordt niet aangepakt.

Uiteraard luidt de tegenwerping van degenen die met onderzoek bezig zijn dat men wel gedwongen is om in het domein van de positieve heuristiek te werken omdat men anders moeilijk steun kan verwerven en bijna niet kan publiceren. Naar aanleiding hiervan is ook een kritische beschouwing betreffende de beoordeling van lopend wetenschappelijk onderzoek gewenst. De huidige methode die vooral stoelt op het meten van 'output' in de zin van aantal publikaties etc. doet geen recht aan de heuristische kracht van die publikaties. Zo langzamerhand dringt wel het besef door dat een onderzoeksgroep met relatief weinig publikaties in gerenommeerde 
tijdschriften beter kan zijn dan een groep die veel publiceert maar in tujjdschriften van minder allooi. Het zou de beoordeling echter nog meer ten goede komen als wij ook aandacht zouden besteden aan de betekenis van onderzoeksresultaten in heuristische termen.

\section{Het hypertensieonderzoek in de naaste toekomst.}

Welke vraagstellingen in het hypertensieonderzoek zijn nu van bijzonder belang voor exploratie in de naaste toekomst? In de eerste plaats die welke betrekking hebben op het ontstaan van hoge bloeddruk. Wanneer wij het vó́rkomen van hypertensie nader beschouwen, dan valt op dat deze aandoening zich soms op betrekkelijk jeugdige leeftijd manifesteert, namelijk zo rond het twintigste levensjaar, maar vaak ook pas zo tussen het veertigste en het vijftigste jaar. Nu kan dat ten dele te maken hebben met de omstandigheid dat bloeddrukverhoging vaak bij toeval wordt vastgesteld en dat het dus heel goed mogelijk is dat de hypertensie al lang bestaat op het moment dat zij ontdekt wordt. Met voorbijgaan aan deze mogelijkheid blijft het zo dat wij van een aantal patiënten van middelbare leeftijd redelijk zeker weten dat zij nog maar betrekkelijk kort hypertensief zijn. Gegeven de tendens van de bloeddruk om te stijgen met de leeftijd, lijkt het er dus op dat er snelle en langzame stijgers zijn. Gewoonlijk besteden wij aan dit verschil weinig aandacht en zijn wij geneigd alle patiënten met hypertensie over één kam te scheren. Met uitzondering van enkele kleine prikacties is er dan ook geen systematisch onderzoek verricht naar de factoren die deze interindividuele verschillen in stijgsnelheid bepalen. Nog afgezien van de logistieke problemen die aan een dergelijk langdurig onderzoek verbonden zouden zijn, zijn de meeste onderzoekers op het moment dat zij het belang van de vraagstelling gaan inzien al op een leeftijd aangekomen dat zij zelf het antwoord niet meer kunnen vinden. Niettemin zou het wel eens zo kunnen zijn dat er belangrijke pathogenetische en pathofysiologische verschillen bestaan tussen een jongere en een al wat oudere met pas ontstane hypertensie, in dezelfde zin zoals die bestaan tussen type I en type II diabetes mellitus. Het lijkt mij dan ook raadzaam om deze mogelijkheid verder te exploreren. Een mogelijke uitkomst zou dan wel eens kunnen zijn dat wij ons idee over hypertensie moeten bijstellen. Tot nu toe zien wij hypertensie namelijk nog als een aandoening 'in its own right', die mettertijd aanleiding geeft tot allerhande orgaancomplicaties. Het is echter geenszins uitgesloten dat de verhoging van de druk op zichzelf een orgaancomplicatie is en een toestand aanduidt waarbij het vaatstelsel irreversibel beschadigd is door een 
andere, nog niet geïdentificeerde factor of ziekte.

Iets gemakkelijker toegankelijk is het onderzoek naar de korte termijn variaties in de bloeddruk. Al vrij vroeg in de historie van het hypertensieonderzoek heeft men de spontane fluctuaties in de bloeddruk onderkend zonder dat duidelijk was welk mechanisme hieraan ten grondslag lag. Vooral door de komst van automatische bloeddrukmeters is de kennis omtrent het patroon van veranderingen flink toegenomen, maar het is nog absoluut onduidelijk wat de oorzaak van de drukschommelingen is. Het is intussen niet ongebruikelijk dat patiënten die op grond van hun bloeddruk overdag tot hypertensielijder zouden worden bestempeld, tijdens hun slaap bloeddrukwaardlen laten zien die zouden kunnen passen bij shock. Tot nu toe weten wij niet wat de betekenis hiervan is. Het onderzoek hiernaar dat in Rotterdam reeds gestart was, zal hier in Maastricht zeker worden voortgezet. Ook is het wenselijk dat er een grootschalig onderzoek van de grond komt naar de waarde van een 24-uurs bloeddrukmeting met betrekking tot de prognose op langere termijn. Al veel te vroeg heeft deze techniek zijn weg gevonden naar de algemene praktijk. Er wordt al onderhandeld over tarieven, terwijl wij nog niet eens weten of het zinvol is om deze methode op grote schaal toe te passen.

Een belangrijk aspect in het toekomstige hypertensieonderzoek dient de bestudering van regionale circulatiegebieden te zijn. De in Maastricht ontwikkelde technieken voor metingen aan de microcirculatie zijn op dit moment echter nog alleen maar toepasbaar op vaatgebieden die waarschijnlijk slechts van beperkte betekenis zijn voor het hypertensieonderzoek. Wel dient de verdere bestudering van de regulatie van de coronaire circulatie en de doorbloeding van de nier met grote voortvarendheid te worden aangepakt. Recent is ontdekt dat ook de bloedstroom door de long van wezenlijke betekenis is voor de hemodynamiek in de grote circulatie. Dit opent een duidelijk nieuw perspectief. Een zeer hoge prioriteit heeft tenslotte het onderzoek naar de hersencirculatie.

Ook op het vlak van de behandeling liggen er nog vele vragen. Op dit moment kunnen wij niet veel anders doen dan bij vrijwel iedereen met hypertensie een behandeling in te stellen. Toch weten wij dat niet elke patiënt met verhoogde bloeddruk een complicatie zal krijgen en dat in een aantal gevallen therapie waarschijnlijk overbodig is. Er is dan ook én aspect aan het hypertensievraagstuk dat een aanpak in de hoogste versnelling vereist. Wij zullen methoden moeten zien te vinden waarmee wij beter dan 
tot nu toe mogelijk is, kumnen voorspellen welke patiënten het grootste risico lopen op een complicatie en wie het meest gebaat is bij therapie. Het ligt in de lijn der verwachtingen dat hier hoge ogen gegooid kunnen worden met niet-invasieve ultrageluidstechnieken.

Er bestaat tegenwoordig onder klinische onderzoekers een sterke neiging om steeds meer onderzoek te verrichten bij normale vrijwilligers. De verklaring hiervoor moet ongetwijfeld gezocht worden in het fenomeen dat patiënten zich niet meer zo gewillig lenen voor allerhande experimenten. Naast het echte proefkonijn, dat bij nadere beschouwing overigens meestal een al dan niet hypertensieve rat blijkt te zijn, is nu de vrijwilliger opgestaan die er niet voor terugdeinst om zich in ruil voor $C D$-bon of equivalente beloning te onderwerpen aan invasief hemodynamisch onderzoek of aan hormonale manipulaties. Het is echter de vraag of deze normale vrijwilliger werkelijk het antwoord zal kunnen geven op een toch in essentie klinische vraagstelling. Immers, voor de klinicus is van belang welke mechanismen het normale functioneren verstoren, hoe zij dat doen en hoe de ontsporingen tot staan kunnen worden gebracht. De vragen waarmee de klinicus zich in zijn praktijk ziet geconfronteerd, hebben betrekking op patiënten en dienen dan ook in de eerste plaats bij patiënten te worden onderzocht. Het hypertensieonderzoek heeft ondertussen wel laten zien dat wij hiermee ook vaak méér aan de weet komen omtrent de normale situatie dan met klinische fysiologie alleen. Deze constatering sluit dan ook fraai aan bij wat 400 jaar geleden al door de Engelse filosoof Sir Francis Bacon betoogd werd. Hij immers pleitte ervoor om het experiment te gebruiken als middel voor kennisvermeerdering en om derhalve de natuur in een toestand te brengen waarin zij normaal niet verkeert. Ziekten zijn als het ware ook een weerspiegeling van een verstoorde natuur, waarbij zaken aan het licht kunnen komen die normaal verborgen blijven en die dus op zichzelf als experiment in Baconiaanse zin beschouwd kunnen worden.

Dames en heren, niet alleen in de kliniek, maar ook in het onderzoek geldt dat hypertensiè zich niet aan één specifiek aandachtsgebied houdt. Overal ter wereld houden vogels van allerlei pluimage zich hiermee bezig. Zo is op dit gebied in de afgelopen jaren belangrijk werk verricht door epidemiologen, nefrologen, endocrinologen, cardiologen, farmacologen en zelfs door chirurgen en radiologen. Dat dit soms tot bizarre situaties aanleiding geeft, wordt geillustreerd door het werk van de Amerikaanse onderzoekers Hollenberg en Williams, beiden werkzaam in het Peter Bent Brigham Hospital (thans: Brigham and Women's Hospital) te Boston, die 
zich in aan elkander grenzende laboratoria maar ieder vanuit een ander aandachtsgebied, bezighielden met de bestudering van mechanismen van bloeddrukverhoging. Bij toeval kwamen zij erachter dat zij op eenzellfde spoor zaten, maar pas nadat zij de handen ineen geslagen hadden, kreeg hun ondlerzoek meer betekenis. Hier waren als het ware twee auguren aan het werk die beiden eenzelfde soort verschijnselen waarnamen, maar bij hun interpretatie van die verschijnselen een verschillende richting uitkeken. Hoewel het zeker nuttig en nodig is dat bepaalde deelaspecten van het hypertensieprobleem op een superspecialistische manier worden geëxploreerd, schuilt er een groot gevaar in de fragmentarische benadering en interpretatie van deelspecialisten. Ik pleit dan ook voor een integrale aanpak door klinisch onderzoekers die voldoende generalist zijn. Dat neemt uiteraard niet weg dat daarbij de inbreng van specifieke deskundigheid vanuit de basiswetenschappen onontbeerlijk is. Ik prijs mijzelf dan ook gelukkig dat hier in Maastricht binnen het Instituut Hart- en Vaatziekten een onderzoeksklimaat is gecreëerd dat het inderdaad mogelijk maakt om in nauwe samenwerking met andere vakgroepen het hypertensieprobleem te lijf te gaan en volgens een thematische benadering aan wetenschappelijke programma's te werken.

\section{De toekomst van de interne geneeskunde.}

Heeft behalve de hypertensie ook de interne geneeskunde nog een toekomst? Ik denk het wel, maar dan in een andere vorm dan nu het geval is. Het is de internist enigszins vergaan als onze augur uit de Romeinse tijd. De augur, een generalist die meerdere soorten verschijnselen moest kunnen interpreteren, begon namelijk na de tweede Punische oorlog geleidelijk aan invloed in te boeten. Daarentegen werden de haruspices steeds belangrijker. Een haruspix was iemand die alleen voorspellingen deed op grond van het schouwen der ingewanden (darm, lever). Hier dringt zich dus een zekere analogie op met het werk van een deelspecialist, met name degene met het aandachtsgebied gastroenterologie. De techniek van het darmschouwen werd door de Romeinse overheid als een uiterst belangrijke verrichting beschouwd waar een goed tarief tegenover stond en die de beoefenaars van deze kunst veel aanzien verschafte. Dat sommigen het overdreven karakter hiervan wel inzagen, moge blijken uit een geschrift van Cicero waarin hij de oude Cato laat verzuchten dat deze niet begrijpt waarom de ene haruspix niet in lachen uitbarst als hij de andere tegenkomt.

Waarom vertel ik u dit? Het is namelijk een illustratie van het feit dat 
overheden vanouds altijd erg gecharmeerd zijn van lieden die bepaalde kunstjes beheersen en minder oog hebben voor degenen die door reflectie en redenering tot oordelen komen die minstens zo belangrijk zijn. Ik doel daarbij uiteraard op het feit dat ook nu in allerlei scenario"s die voor de overheid uitgangspunten voor beleid zijn, zeer veel aandacht wordt geschonken aan deelspecialistische ontwikkelingen terwijl de inwendige geneeskunde nauwelijks aan bod komt. Het lijkt er op alsof voor de overheid de inwendige geneeskunde als overkoepelend specialisme niet bestaat.

Dat er weer enige vorm van assimilatie van deelspecialismen nodig is en dat de interne geneeskunde zich weer moet manifesteren als een volwaardig vak, wordt thans nauwelijks meer betwijfeld maar de middelen om zoiets in de huidige structuur te bereiken zijn vrijwel niet voorhanden. Helaas moet geconstateerd worden dat zelfs een eerbiedwaardige vereniging als de Nederlandsche Internisten Vereeniging hierin tekort schiet, ja zelfs een politiek voert die een averechts effect zal blijken te hebben. In haar pogingen om de desintegratie van de interne geneeskunde een halt toe te roepen, heeft zij namelijk onlangs het zogenaamde aandachtsgebied ingesteld. Dit houdt in dat een assistent in opleiding tot internist zich gedurende de laatste anderhalf jaar van deze opleiding kan toeleggen op een bepaald deelgebied, laten wij om een willekeurig voorbeeld te nemen, zeggen de nefrologie. Na voltooiing van de opleiding kan de betreffende figuur zich dan internist met aandachtsgebied nefrologie noemen. In de praktijk wordt dit gewoonlijk verkort tot internist-nefroloog. Dat hier sprake is van een contradictio in terminis (immers een internist heeft een algemene taak, terwijl de nefroloog per definitie juist een beperkt terrein bestrijkt), is kennelijk voor niemand een probleem. Waar bovendien in deze hybride omschrijving de nadruk ligt op de tweede term waardoor onvoldoende recht wordt gedaan aan het begrip internist, zal er geen goede voedingsbodem zijn voor reïntegratie. Inmiddels blijkt dan ook dat zeer veel internisten die reeds praktisch werkzaam waren en de gelegenheid kregen zich alsnog te laten registreren in een aandachtsgebied, van deze mogelijkheid gebruik hebben gemaakt. Daarnaast heerst bij de meeste assistenten in opleiding tot internist de opvatting dat de kansen op werk aanzienlijk toenemen als men een erkenning heeft in een van de aandachtsgebieden. Hiermee is het separatisme feitelijk onvermijdbaar geworden, want wie zal zich nog gewoon internist durven noemen? In het nieuwe systeem zullen de internisten-deelspecialist (om deze term toch nog maar even te gebruiken) bovendien de neiging hebben om hun territorium scherp af te bakenen. Dit komt onder andere naar voren in de strenge regels 
die opgesteld zijn voor registratie in een aandachtsgebied. lemand die zich bijvoorbeeld veel bezighoudt met de diagnostiek en behandeling van patiënten met nierziekten komt toch niet voor registratie als internistnefroloog in aanmerking als hij niet ook gedurende enige tijd getraind is in dialyse en transplantatie. Zonder nu het belang van deze werkterreinen te willen onderschatten, komt het mij voor dat iemand zonder specifieke opleiding in dialyse of transplantatie ook best internist met aandachtsgebied nefrologie zou kunnen zijn, met in dat geval misschien iets meer nadruk op de term internist. Het moet toch heel goed mogelijk zijn dat iemand zich volledig wijdt aan het bestuderen van de pathogenese van glomerulonefritis of andere nierziekten zonder de ambitie te hebben om betrokken te zijn bij nierfunctievervangende therapie. Uiteraard zal men mij nu tegenwerpen dat registratie als internist-nefroloog in een dergelijk geval het risico inhoudt dat de betreffende figuur op een gegeven moment toch gaat dialyseren zonder dat hier controle op is. Dit is natuurlijk waar en het brengt ons op een tweede element dat meegespeeld heeft bij de instelling van aandachtsgebieden, namelijk de behoefte aan controle en kwaliteitsbewaking.

Tot voor kort kenden wij in Nederland een systeem waarin men na erkenning als internist zonder verdere controle van bovenaf tot aan het pensioen geregistreerd bleef. Onlangs is de herregistratie ingevoerd, waarbij iedere specialist telkens voor een periode van vijf jaar erkend wordt. Blijkt aan het eind van de vijfjaars periode dat hij nog steeds praktisch werkzaam is gedurende een bepaall aantall uren per week, dan volgt vanzelf herregistratie voor een volgende periode van vijf jaar. Waar nu de eisen voor herregistratie betrekkelijk vaag zijn voor de internist met algemene taken, is herregistratie in een aandachtsgebied aan strenge regels gebonden en alleen mogelijk als men nog voldoet aan de criteria zoals in de opleidingseisen weergegeven. Dit moet natuurlijk tot bizarre situaties gaan leiden. Neemt u bijvoorbeeld een internist met het aandachtsgebied gastroenterologie. Als deze geen scopieên meer verricht, zal herregistratie in zijn aandachtsgebied moeilijk worden, maar op grond van zijn kwalificatie als internist mag hij wel scopieën blijven doen. Dit betekent dus dat ten anzien van cenzelfde soort verrichting een generalist niet gecontroleerd hoeft te worden en een deelspecialist wel. Dit kan natuurlijk niet de bedoeling van de nieuwe regelgeving zijn geweest en ik moet dan ook constateren dat de instelling van aandachtsgebieden ook op het vlak van de kwaliteitsbewaking een negatieve uitwerking zal hebben. Alle goede bedoelingen ten spijt, lijken dus zowel het streven naar reintegratie als de ambitie om de kwaliteit van de patientenzorg te 
bevorderen in de huidige opzet tot mislukken gedoemd.

Het probleem gaat nog verder. Tot nu toe vinden wij dat men na erkenning als specialist in de interne geneeskunde, eventueel in een aandachitsgebied, werkzaam moet zijn op alle onderdelen van het betreffende gebied. Toch beseft iedere (deel)specialist dat hij niet in staat is om aan alle aspecten van zijn vakgebied evenveel aandacht te geven. Ik noemde u reeds de nefroloog die zich liever met glomerulonefritis dan met dialyse bezighoudt. Zo zijn er meer voorbeelden te geven. Binnen het gebied van de hematologie-oncologie vindt men sommige specialisten die zich vooral toeleggen op de stolling en andere voor wie kanker de grootste uitdaging vormt. In de gastroenterologie dreigt al een differentiatie op te treden in de richting van de hepatologie en om even dicht bij huis te blijven, wordt er ook al gesproken over hypertensiologie als deelspecialisme. Op mondiaal niveau maakt de World Hypertension League zich hier zelfs sterk voor. Men hoeft beslist geen Nostradamus of augur te zijn om in te zien dat deze wijze van voortschrijdende specialisatie uiteindelijk zal leiden tot een toestand waarin elke ziekte haar eigen specialisten kent. Hoewel ik besef dat deze toestand waarschijnlijk niet op korte termijn bereikt zal worden, is er toch sprake van een naar mijn mening heilloze ontwikkeling die onder andere voortvloeit uit het feit dat wij vast willen blijven houden aan de huidige traditionele structuur van specialisatie en aan de als een Ne Plus Ultra vaststaande contouren van gevestigde vakgebieden.

Is er dan een alternatief? Ik denk het wel, als wij maar bereid zijn om onze opleidingseisen en onze visie op de praktische uitoefening van het vak te herzien. Men kan zich de (interne) geneeskunde namelijk opgebouwd denken uit algemeen toepasbare theoretische en praktische kennis enerzijds en bekwaamheid in specifieke verrichtingen of behandelingen anderzijds. Vooral verrichtingen zijn kunstjes die door iedereen aangeleerd kunnen worden. Men behoeft beslist geen gastroenteroloog te zijn om toch uit te kunnen blinken in scopieën. Het is ook niet bij voorbaat uitgesloten dat een internist een bijzondere vaardigheid opbouwt in angiografisch onderzoek, om nog maar eens een willekeurig voorbeeld te noemen. Het zal u duidelijk zijn waar ik naar toe wil: geen exclusieve koppeling van bepaalde vaardigheden aan een specifiek aandachtsgebied of misschien zelfs vakgebied. Men zou zich immers best een situatie kunnen voorstellen waarin iemand wel gebreveteerd is om als aandachtsgebied de nefrologie te beoefenen, maar dat registratie als dialyse-arts een apart certificaat vereist. Op deze manier zou diallyse overigens ook makkelijker toegankelijk kunnen 
worden voor andere specialisten, bijvoorbeeld die welke werkzaam zijn op een intensive care. Ilk denk dat de tijd voorbij is dat wij aan eén bepaalde registratie algemene rechten kunnen ontlenen en dat een systeem van deelcertificatie nodig wordt, dat ook buiten de interne geneeskunde geldigheid moet hebben. Wij zullen af moeten van het idee dat alle vertegenwoordigers van een aandachtsgebied precies hetzelfde moeten kunnen en doen. Waarom kan een nefroloog geen endoscopisch onderzoek doen, waarom zou een in intensive care geïnteresseerde specialist niet zelfstandig kunnen dialyseren en waarom zou iemand niet tegelijk bij zowel niertransplantaties als beenmergtransplantaties betrokken kunnen zijn?

Uitgaande van de gedachte dat bepaalde vaardigheden door iedereen geleerd kunnen worden, zou de flexibiliteit en inzetbaarheid van internisten wel eens enorm kunnen toenemen door aan de assistent in opleiding de keuze te laten welke kunstjes hij wil leren. Op deze manier introduceert men zogenaamde 'keuzepakketten', die uiteindelijk bepalend zijn voor wat de assistent na registratie als internist mag doen. Zaken als herregistratie en kwaliteitscontrole worden daardoor ook makkelijker want voor iedereen gelden dan dezelfde criteria. Men toetst immers op vaardigheden.

Uit een recent rapport van de Gezondheidsraad over kwaliteit van medisch handelen blijkt dat specialisten nogal eens vinden dat hún specialisme en niet een ander bij uitstek geschikt is om een bepaalde verrichting te doen. Quasi wetenschappelijke motieven en een ontroerende zorg om kwaliteitsbewaking verdoezelen echter meestall waar het in werkelijkheid om draait: de financiële vergoeding. Wanneer elke arts de gelegenheid krijgt om een verrichting te leren en geregeld getoetst wordt op zijn bekwaamheid daarin, wordt de kwaliteit meer gediend dan wanneer er controversen blijven bestaan tussen specialismen omtrent het vermeende recht op verrichtingen. Als dan ook nog de huidige, niet meer passende honoreringsstructuur, afgeschaft wordt en er zowel in het academisch ziekenhuis als in de periferie een vergelijkbaar carrière-perspectief ontstaat, zijn er goede mogelijkheden voor andersoortige differentiatiegebieden in de geneeskunde.

\section{Thematisch gerichte patientenzorg.}

De differentiatie binnen de interne geneeskunde heeft, zoals ik reeds heb aangegeven, geleid tot het instellen van aandachtsgebieden. Mijns inziens hollen wij hiermee achter de feiten aan en zijn wij onvoldoende voorbereid op grotere veranderingen die zich binnen het vakgebied zullen (moeten) gaan 
voltrekken. Immers, conservatief als wij zijn proberen wij krampachtig vast te houden aan het 'Ne Plus Ultra' van de bestaande structuur. Toch valt deze op den duur niet te handhaven.

De thans gangbare indeling in deelspecialismen berust op de geleidelijke uitbreiding van kennis en onderzoektechnieken met betrekking tot orgaansystemen. Zo hebben bijvoorbeeld endoscopische technieken in belangrijke mate bijgedragen aan de ontwikkeling van de gastroenterologie, terwijl toegenomen kennis omtrent regelsystemen onder andere de endocrinologie in de lift heeft gezet. Er zijn diverse andere voorbeelden te geven, doch telkens stond in de ontwikkeling een orgaan of orgaansysteem centraal. Vanuit ons wereldbeeld waarin de mens als organisme steeds meer gezien werd als een complex van afzonderlijke, in nauwe harmonie met elkaar werkende organen, is dat ook niet vreemd. Echter, als gevolg van meer recente ontdekkingen gaat deze anatomisch-mechanische visie geleidelijk over in een op functie gebaseerde visie. Het is duidelijk geworden dat de basale processen in cellen van orgaan tot orgaan grote overeenkomsten vertonen, maar dat de uitwerking hiervan bepaald wordt door de lokalisatie van deze cellen, als het ware door de structuur van de matrix waarin zij ingebed zijn. Evenzo hebben de ontwikkelingen binnen diverse deelspecialismen geleid tot parallelle hypothesen omtrent de pathofysiologie van ziekten en mogelijkheden tot behandeling. Op grond van deze overwegingen meen ik dat de differentiatie binnen de interne geneeskunde in plaats van een orgaangericht meer een functioneel, zo u wilt thematisch karakter dient te krijgen. Laat ik dit aan de hand van enkele voorbeelden verduidelijken.

Historisch gezien is transplantatiegeneeskunde bij uitstek het terrein van de nefroloog geweest. Dit komt omdat het eerste orgaan dat met succes getransplanteerd kon worden, een nier was. Het is duidelijk dat degenen die het dichtst bij een bepaalde ontwikkeling staan, ook het meest aangewezen zijn om dit aspect te integreren in hun praktijk. Thans echter bevinden wij ons in een tijdperk waarin wij naast nieren ook alvleesklieren, beenmerg, harten en wat dies meer zij kunnen transplanteren. De immunologische principes die daarbij aan de orde komen en de bestrijding van afstotingsreacties zijn met betrekking tot de diverse organen echter niet wezenlijk verschillend en het zou de ontwikkelingen alleen maar ten goede komen als de beschikbare krachten gebundeld zouden kunnen worden. Ik pleit er dan ook voor om transplantaties los te koppelen van specifieke aandachtsgebieden en om een aparte, uiteraard sterk op de immunologie 
gebaseerde, richting van algemene transplantatiekunde op te gaan.

Een ander voorbeeld. Zoals ik $\mathrm{u}$ al zei, is hypertensie een afwijking die vanuit vele aandachtsgebieden is benaderd. Als uitvloeisel van het diverse onderzoek zijn wij niet alleen over het hypertensieprobleem, maar vooral ook over de sturing van de bloedcirculatie veel wijzer geworden. De algemene principes die daarbij naar voren zijn gekomen, blijken inmiddels ook geldigheid te hebben voor ontregelingen van de circulatie zoals die zich kunnen voordoen bij sommige stoornissen in lever- of nierfunctie of bij een verminderde pompfunctie van het hart. Daarmee wordt vanuit de hoge druk sfeer een soepele overgang bewerkstelligd naar de andere kant van het spectrum van circulatoire afwijkingen: shock. Ook bij het ontstaan van atherosclerose (aderverkalking) alsmede enkele andere aandoeningen spelen circulatoire mechanismen een grote rol. Er valt dan ook veel voor te zeggen om een aandachtsgebied, gericht op de pathologie van de circulatie, te creëren. De goede verstaanders zullen ondertussen wel begrijpen dat ik in een dergelijk aandachtsgebied ook een rol voor dialyse zie weggelegd. De intensive care geneeskunde gaat ons iñ dit model al voor. Al lang kan de interne geneeskunde niet meer het alleenrecht claimen op de intensive care, maar moet zij de verantwoordelijkheid delen met chirurgen en anesthesisten. Dit gaat weliswaar nog maar moeizaam, maar toch zijn er inmiddels door deze groepen gezamenlijke opleidingseisen geformuleerd.

Wanneer wij inderdaad in staat zouden zijn om in plaats van orgaangericht thematisch te gaan werken, wordt daarmee fundamenteel geknaagd aan de traditionele grenzen van vakgebieden. Immers, in de zojuist geschetste mogelijke stromingen (transplantatie, circulatie) is naast internisten ook plaats voor chirurgen, radiodiagnosten en een enkele cardioloog. Evenzo kan gedacht worden aan een collectief van internisten, radiodiagnosten en chirurgen, die op gastroenterologisch gebied samenwerken. De noodzaak tot een steeds verder gaande deelspecialisatie maakt dan plaats voor een intensief samenwerkingsverband tussen vakgroepen. Pathofysiologisch georiënteerde artsen in plaats van steeds meer orgaan- of ziektegerichte artsen. Men zou zelfs nog verder kunnen gaan en bijvoorbeeld alle endoscopisten in een dienstverlenende groep onderbrengen, die zelfstandig opereert op alle bereikbare organen.

Een dergelijke thematische benadering begint verdacht veel te lijken op de matrixstructuur zoals die voor het onderzoek en het onderwijs aan deze faculteit reeds is ingevoerd. Gezien deze voorgeschiedenis lijkt mij dan ook dat het Academisch Ziekenhuis in Maastricht bij uitstek geschikt moet zijn 
om te experimenteren met een dergelijke nieuwe opzet van de patientenzorg.

Het is onwarschijnlijk dat een ontwikkeling zoals ik die hier schets, makkelijk tot stand komt. Misschien moet de interne geneeskunde inderdaad eerst volledig desintegreren alworens er als een phoenix uit zijn as een nieuwe vorm van ünternistische geneeskunde, gekenmerkt door functionele differentiatie, tevoorschijn komt. Zeker is evenwel dat de huidige neiging tot regelgeving het vak geen goed zal doen en dat wij er verstandig aan doen om bijtijds hel roer om te gooien.

De opleiding zou nu zo gestructureerd moeten worden dat men gedurende de eerste vier jaar een algemene vorming krijgt met daarin besloten een aantal verplichte trainingen in bijvoorbeeld endoscopische technieken en intensive care geneeskunde. Na deze vier jaar zou men dan als internist moeten kunnen gaan werken. In deze sluit ik mij dus aan bij het idee van Meinders om, wat hij noemt, 'primaire internisten' op te leiden en die na maximaal vier jaar te breweteren voor de algemene praktijk. In een dergelijke opzet past het om een deelspecialistische vorming, hetzij in een algemeen aandachtsgebied als nefrologie hetzij op een beperkter terrein als (acute) dialyse, los te koppelen van deze algemene vorming. Dat betekent dat het volgen van een aandachtsgebied ook op een later tijdstip moet kunnen vallen, eventueel dus pas na een aantal jaren praktijkvoering. Op deze manier gaat men dus toe naar een systeem waarin de ene internist niet meer precies gelijk is aan de andere omdat datgene wat zij in hun pakket hebben verschilt. Ook is het dan mogelijk dat men zijn aandachtsgebied of verrichtingenpakket na verloop van tijd aanpast aan de door de omstandigheden ingegeven behoeften.

Naar mijn idee zouden de echte deelspecialisten alleen werk moeten verrichten in het derde echelon waar zij vooral een belangrijke onderzoekstak zullen hebben. Een directe verwijzing door de huisarts naar dilt derde echelon zou in dit systeem niet passend zijn. De tweede lijn met haar overwegend pathofysiologische benadering dient te bepalen wie voor welke aandoening door moet stromen naar een meer orgaangerichte of ziektegerichte derde lijn.

\section{Nawoord.}

Dames en heren, thans ben ik aangeland bij het meer sentimentele deel van deze rede: het dankwoord. Terugkijkend op mijn leven tot nu toe, moet ik constateren dat zeer velen, soms zonder dat zij zich dit bewust waren, ertoe hebben bijgedragen dat ik u nu toespreek. Reeds vroeg had ik het 
bes/luit genomen om geneeskunde te gaan studeren. Uiteraard dank ik mijn ouders voor het feit dat zij het mij mogelijk gemaakt hebben om deze wens in vervulling te doen gaan. Als voorbereiding voor deze studie achtte ik een gymnasiale opleiding essentieel. Mijn liefde voor de klassieke letteren en cultuur is vooral een gevolg van de inspirerende lessen van Tichelman en Pos. Hun enthousiasme van destijds heeft mij mede gebracht tot de latinistische opening van deze oratie. Vooral Pos heeft ervoor gezorgd dat ik mijn drang tot generalisme toen al kon botvieren. Tijdens mijn studie geneeskunde zijn het achtereenvolgens de neuroloog Van Vliet, de anatomen Moll en Krediet en de huisartsen Van Trommel, Van der Does en Hamburger geweest die mij hebben laten zien dat er méér te doen viel dan alleen het volgen van colleges.

Het besef dat de specialist, naast zijn taak in de directe patientenzorg, ook behoort te werken aan de ontwikkeling van zijn vakgebied is mij vooral bijgebracht door mijn opleider in de interne geneeskunde, de hooggeleerde Birkenhäger. Beste Willem, vele jaren hebben wij samengewerkt en in die tijd ben jij van leermeester tot goede vriend geworden. Juist jij benadrukte altijd het belang van 'debunking', het ontkrachten van al te gemakkelijke of te populaire hypothesen door kritische beschouwing en door eigen onderzoek, waarin voor een creatieve benadering meer plaats was dan voor een verstarrend protocol. Ik hoop ook in de toekomst nog vaak van je inzichten gebruik te mogen maken. Beschouw in ieder geval deze dag als een voor jou persoonlijke triomf.

In het Zuiderziekenhuis te Rotterdam hebben in de loop der jaren vele assistenten, verpleegkundigen en analisten hun bijdrage geleverd aan de voortgang van het onderzoek. Ik bedlank hen hier als collectief, niet omdat hun afzonderlijke namen niet belangrijk zouden zijn, maar om de verbondenheid aan te geven die er altijd heeft bestaan.

De benoemingscommissie en het College van Bestuur van de Rijksuniversiteit Limburg dank ik voor de voordracht respectievelijk mijn benoeming tot hoogleraar in de interne geneeskunde, in het bijzonder de hypertensie en de nefrologie. Deze voor nefrologen pur sang wat controversiële beslissing getuigt van een visie die zeer nauw aansluit bij wat ik in het voorafgaande heb betoogd. Komend vanuit een perifere kliniek ervaar ik deze benoeming bovendien als een duidelijk bewijs voor het belang van het niet-universitaire ziekenhuis. Mijn terugkeer naar de Alma Mater sluit een periode af van twintig jaar, waarin ik niet rechtstreeks door de Universiteit ben gevoed. Op één uitzondering na, heb ik al mijn 
coassistentschappen in de periferie gedaan; ik ben opgeleid in de periferie en ik heb daar praktijk gedaan. Ik acht mij dan ook zeer wel in staat tot een oordeel over de waarde van het perifere ziekenhuis bij opleiding en onderzoek. In tegenstelling tot wat veel assistenten in opleiding menen te weten, is het juist het generale karakter van het perifere ziekenhuis dat de opleiding tot internist breder maakt dan deze ooit kan zijn aan de Academie.

Leden van de Raad van Bestuur en leden van de vakgroep Interne Geneeskunde van het Academisch Ziekenhuis Maastricht: ik dank jullie voor de wijze waarop jullie mij als vreemde eend in jullie bijt hebt opgenomen. De angst voor het onbekende bleek ongegrond. Reeds nu, na zo een korte tijd, voel ik mij hier thuis en ik heb er alle vertrouwen in dat de diverse studies die wij nu aan het uitvoeren zijn, tot goede resultaten zullen leiden. In het bijzonder dank ik de voorzitter van onze vakgroep, Guus Flendrig, die op een bijzondere wijze gestalte geeft aan het handhaven van het begrip internist.

Dames en heren studenten, u vormt de rechtvaardiging voor onze aanwezigheid aan de universiteit. Dat schept verplichtingen. Zoals waarschijnlijk vele anderen had ik uitermate ambivalente gevoelens ten opzichte van het Maastrichtse onderwijssysteem. Nu ik er in de praktijk kennis mee heb gemaakt, ben ik er door gegrepen. U kunt ervan verzekerd zijn dat ik mij zeer zal inspannen voor de verdere ontwikkeling van dit systeem.

Tot slot dank ik mijn vrouw Andrea; haar naam betekent 'moed, kracht, energie'. Zonder dat had zij het niet gehaald en zonder haar ik niet.

Dames en heren, titel en thema van mijn rede bleken voor sommigen een enigma te zijn, zoiets als de 'Enigma variations', een prachtig muziekstuk van de Britse componist Elgar. Deze had boven de partituur de zin gezet: The theme never appears (het thema verschijnt nooit). Jarenlang hebben musicologen geworsteld met de vraag wat het enigma kon zijn en hoe het thema ontcijferd kon worden, totdat zij werkelijk gingen geloven dat er geen thema in het stuk zat. Pas in de jaren ' $70 \mathrm{kwam}$ iemand op het heldere idee dat de zin gelezen moest worden als: The theme 'never' appears (het thema 'nooit' verschijnt). Op dat moment pas werd de betekenis duidelijk en kon een Ne Plus Ultra weer vervangen worden door Plus Ultra.

Ik eindig niet, omdat er niets meer is, maar omdat er niets meer is.

Ik heb gezegd. 